Makale Geliş | Received: 04.07.2019.

Makale Kabul | Accepted: 01.08.2019

DOI: $10.18795 /$ gumusmaviatlas.587134

Mavi Atlas, 7(2)/2019: 88-107

Araştırma Makalesi | Research Article

Fatma YILDIRMIŞ

Dr. Öğretim Üyesi | Assist. Prof. Dr Gümüşhane Üniversitesi, Edebiyat Fakültesi, Türk Dili ve Edebiyatı Bölümü, Gümüşhane-TÜRKIYE Gumushane University, Faculty of Letters, Department of Turkish Language and Literature, Gumushane-TURKEY orcid.org/0000-0003-2913-5489

fatma.yildirmis@gumushane.edu.tr

\title{
“Hazal” ve "Sultan Gelin” Filmleri Üzerinden Evliliğe İlişkin Geleneklerin Halk Bilimi Açısından Değerlendirilmesi
}

Öz

Görsel bir sanat olan sinema aracıllğıyla Türk toplumunun toplumsal yapısı ve gelenekleri birçok filme konu olmuştur. Sinema izleyicisi kendi kültürünün aynası olan filmleri zevkle benimsemiş̧ir. Buradan yola çıkarak bu çalışmada, "Hazal" (1979) ve "Sultan Gelin" (1973) adlı iki filmin halk bilimi perspektifinden incelemesi yapılmıştır. Her iki film aynı başrol oyuncusuyla kırsal bölgelerde çekilmiştir. Filmlerde baştan sona evlenme geçiş dönemi ile ilgili geleneklerin işlendiği dikkat çekmektedir. Filmlerde yapılan evliliklerde "levirat" evlilik biçimi ile "başlık parası" geleneğinin katı bir şekilde uygulandığı görülmektedir. Bu bağlamda bu çalışmada Türk sinemasında işlenmiş halk kültürünü yansıtan evlilik geçiş dönemine ait bazı gelenekler değerlendirilmek ve uygulamalı halk bilimi açısından sinemanın kültürel aktarımdaki rolü vurgulanmak istenmiştir. Başlık parası geleneğinin etkisiyle levirat yoluyla evlilik etrafında gelişen evlenme âdetleri folklorik açıdan değerlendirilmiştir. Her iki filmde levirat ve kaçma yoluyla evlilik çeşidinin yanında evlilik isteğinin belirtilmesi, başlık, düğün, nikâh gözlemlenen ortak geleneklerdir. Yüzgörümlüğü sadece "Sultan Gelin" filminde, duvak geleneği ise sadece "Hazal" filminde karşımıza çıkmaktadır.

Anahtar Kelimeler: Sinema, Levirat, Hazal, Sultan Gelin, Gelenekler.

\section{An Evaluation of Traditions related to Marriage in terms of Ethnology through "Hazal" and "Sultan Gelin" Movies}

\begin{abstract}
The Social structure and the traditions of Turkish society are discussed as a topic in many movies through cinema that is a visual art. Turkish audience has adopted movies that represent their culture. Thus, in this study, Hazal (1979) and Sultan Gelin (1973) have been examined from ethnology perspective. Both movies have been made in the countryside with the same actor. Traditions about marriage get attention from the beginning of movies. It is seen that "levirate" and "bride wealth" traditions are practised rigorously. In this context, in this study, it is aimed to evaluate some traditions related to marriage period discussed in Turkish movies and emphasize the role of cinema in cultural transmission in terms of applied ethnology. With the effect of the tradition of "bride wealth", marriage traditions especially levirate has been evaluated in folkloric terms. Beside levirate and elopement in both movies, marriage wish, bride wealth and wedding processes are common traditions. Price for seeing the bride's face appears only in Sultan Gelin and the bride's veil appears in Hazal movie.
\end{abstract}

Keywords: Cinema, Levirate, Hazal, Sultan Gelin, Traditions. 


\section{Giriş}

Toplumları ayakta tutan temel öğelerin başında gelen ve evlilik bağıyla oluşan aile, akrabalık ilişkisi ile bir arada bulunan fertlerin oluşturduğu en küçük sosyal topluluktur. Evlilik, insan hayatının önemli dönüm noktalarından ve geçiş dönemlerinden biridir. Evlenme çağı, eş seçimi, kız isteme, söz ve nişan merasimi, düğün etkinliği, düğün sonrası gibi birçok ritüel insan hayatı için çok önemlidir. Bu nedenle evlilik geçiş dönemi, geri kalmış toplumlardan uygar toplumlara kadar birbirine benzeyen veya birbirinden ayrılan uygulamalarıyla evrensel olma özelliği taşımaktadır.

Ailenin yerine getirdiği temel işlevlerden birkaçı ise şöyle sıralanabilir:

a) Kadın ve erkeğe ihtiyaç duydukları farklı rolleri vermek

b) Çocukların bakım ve yetiştirilmesini sağlamak

c) Kültürün nesiller arasında geçişini sağlamak

d) Karıkoca arasındaki cinsel bağı topluma göre kabul edilir kılmak (Tezcan 1983: 70).

Toplumları meydana getiren ailelerin tesisinde ise belirleyici olan birtakım gelenekler karşımıza çıkmaktadır. Gelenek ise ortak bir coğrafyada, din, dil birliği olan çevresindeki olayları yorumlayan insan topluluklarına ait tutum ve davranışlardır.

Kuşaklar boyunca toplumlar arasında aktarılan davranış biçimleri ve ölçütlerin toplamı olan geleneğin bir bütün olarak benzerlerinden farkı, içinden çıktığ 1 toplumun dil, tarih ve coğrafya değişikliği içinde kendini yeniden üretmesidir (Sözen 2009: 142). Geleneğin durağan olmadığ1 düşünüldüğünde zamanla çeşitliliğinin arttı̆̆1 ve çağa uyum sağladığı göz ardı edilemez. Bu açıdan bakıldığında toplumun bildiği efsanelerin, mitlerin, hikâyelerin ve masalların çeşitli şekillerde tekrar karşısına çıkması gerçekte gereksinim duydukları ortak kültürel belleğin beslenme biçiminin zenginliğidir. Mitolojiden tiyatroya, efsanelerden çizgi romana, halk hikâyelerinden sinemaya kadar dönüştürülen bütün bu anlatımlar uygulamalı halk biliminin ilgi alanını oluşturmaktadır (Tepeköylü 2016: 1005). Öcal Oğuz’un da dediği gibi “XIX. asırda yaşatmak için saklamak amacıyla derlenen halk bilimi ürünleri, artık yaşatmak için yaymak düşüncesiyle uygulanmaktadır." (Oğuz vd., 2002: 8). Teknoloji çağında, çağdaş ve evrensel dili kullanan sinema, ürettiği filmler aracılığıyla toplumların aynası olmaktadır. 1941-81 yılları arasında Türk sineması, ülke politikası, ekonomisi ve sosyokültürel yapısıyla toplumsal gelişim ile aynilik göstermektedir. Türklerin toplumsal yapısı, gelenekler ve görenekleri filmlerin konusunu oluşturarak çoğunlukla romantik yaklaşımla ortaya koyulmuştur (Candemir 2006: 11). Bu makalenin amac1, Türk 
Fatma YILDIRMIŞ, “'Hazal’ ve 'Sultan Gelin’ Filmleri Üzerinden Evliliğe İlişkin Geleneklerin Halk Bilimi Açısından Değerlendirilmesi”, Mavi Atlas, 7(2)/2019: 88-107

sinemasına işlenmiş halk kültürünü yansıtan evlilik geçiş dönemine ait bazı unsurları değerlendirmek ve uygulamalı halk bilimi açısından sinemanın kültürel aktarımdaki rolünü vurgulamaktır. Bu bağlamda "Hazal" (1979) ve "Sultan Gelin" (1973) adlı iki filmin incelemesi yapılmıştır. Başlık parası geleneğinin etkisiyle levirat yoluyla evlilik etrafinda gelişen evlenme âdetleri folklorik açıdan değerlendirilmiştir.

\section{Filmlerin Özetleri}

\subsection{Hazal}

"Hazal” filminin yönetmenliğini Ali Özgentürk, yapımcılığını Abdurrahman Keskiner yapmış ve senaryosunu Onar Kutlar ile Ali Özgentürk yazmıştır. Filmin türü dramdır, Batman'da Gönüllü Köyü'nde çekilmiştir. Filmin başrol oyuncuları ise Türkan Şoray (Hazal) ve Talat Bulut (Emin)'tur.

Türkan Şoray, Hazal adıyla başlık parası karşılığında muhtarın oğlu Beşir'le evlendirilir. Fakat Hazal'ın gönlü, duvarcı ustası Emin'dedir. Beşir, köyü terk edince Hazal, Beşir'in küçük erkek kardeşiyle evlendirilir. Filmdeki olaylara ilişkin açıklamalar filmin başlangıç kısmında gözleri görmeyen ve hasır işleyen birkaç kişinin ağzından anlatilır.

Bu düğün hazırlığına ben başladım; muhtarın büyük oğlu Beşir ile adı gibi ceylan gözlü fukara Hazal için. Beşir bu köyden gitmiştir bir daha da dönmemiştir. Beşir bu köyden ilk çıkandır. Beşir ölünce bu dügün hasırı da ceylan gözlü Hazal da Beşir'in kardeşi Ömer'e kalmıştır. Ağlarız Hazal'a ağlarız. Yanmıştır Hazal, fukara ailesinin başlık parasını kurtarmak için yanmıştır. Duvarcı Emin usta da yanmıştır. O da istemişti Hazal'1, parası yetmemişti. Başlık parası ödenen gelin, ölenin kardaşına helaldir. Bu hasır Hazal ile Ömer'in evliliklerinin örtüsü. Düşünme ferman buyruk ağamızındır. Uyandık, kaderi bu hasıra işledik. Kimsenin gücü yetmez değiştirmeye...

"Hazal" filminin başlangıcı filmin trajik yönlerinin de habercisidir. Farklı bir dilde seslendirilen ağıt niteliğinde bir türkü, içli içli ağlayan bir anne, hüzünlü insanlar, sessiz, tepkisiz, konuşmayan, gülmeyen, gelinliği giydirilen gelin sahneleri dikkat çeker.

Film, çeyizi taşınan Hazal'ın gelinlik giymesiyle başlar. Filmde sanki dinî bir unsurmuş gibi başlık parasının bir hoca huzurunda ve topluluk karşısında verilip alınması işlenmekle birlikte Hazal'ın evden çıkışı bir düğün coşkusu şeklinde değil de annesinin ağlamaları ile bir matem havasında verilmeye çalışılmıştır. Hocanın duası nezaretinde nikâh yapıldığı anlaşılan bir durumdan sonra başlık ödemesi yapılır ve mutsuz, eğlencesiz, çalgısız, oyunsuz bir düğün gerçekleşir. Fon müziğinde hüzünlü bir türkü söylenir ve filmin baştan sona bir trajedi olduğu gözler önüne serilir. Zira Ömer daha bir çocuktur, Hazal ise güzeller güzeli bir genç kızdır. Beşir düğün olmadan gittiği için Hazal, 
Fatma YILDIRMIŞ, “'Hazal' ve 'Sultan Gelin’ Filmleri Üzerinden Evliliğe İlişkin Geleneklerin Halk Bilimi Açısından Değerlendirilmesi”, Mavi Atlas, 7(2)/2019: 88-107

Ömer'le evlendirilir. Her ikisi de kurbandır bu evlilikte; Hazal kadınlığını, Ömer çocukluğunu yaşayamaz. Bütün duygular, tıpkı kendileri gibi tutsaktır. Ömer ailenin soyunu çoğaltacak koca adam olmuştur, arkadaşlarıyla oynaması yadırganır. Oldukça ilkel bir kadın olan Ömer' in annesi, istediği gibi davranılmadığında saldırganlaşarak hem Ömer'i hem Hazal'ı yıpratır. Yaşadıklarına dayanamayan Hazal baba ocağına dönse de orada da kabul görmez. Bu durum, "gelinin gelinlikle girdiği evden kefenle çıkacağı" anlayışıyla örtüşmektedir. Filmde köylü; toplu çocuk ölümleri, intihar, yangın gibi afetlerle sınanmaktadır. Köylü bunu köyden geçecek olan yol projesine dayandırırken bize göre bu, Hazal'ın kara bahtının yansımasıdır. Etrafındaki tüm baskıya rağmen Hazal, bir kadın olarak duygularını yaşamaktan geri durmaz. Eskiden beri onu tutkuyla seven duvarcı Emin'e kayıtsız kalmaz, gizlice buluştukları bir gece onunla birlikte olur. Gizli âşıklar, yasak aşklarını yaşamaktan kaçınmaz. Ancak bu, töreleri yıkmak, dâhil oldukları düzen içinde affolunmaz günahı işlemek demektir. Kaçmaktan başka çare yoktur, onlar da öyle yapar. Âşıklar, başkaldırdıkları düzenden kaçmak ister; ancak bu hiç kolay değildir. Ortada "temizlenmesi gereken bir namus meselesi" vardır. Filmin sonunda sevdiğiyle kaçan Hazal, köylü tarafından ölüm cezasına çaptırılır. Emin ile Hazal'ın cesetleri at üzerinde köye getirilince filmin ilk başında gözleri görmeyen hikâye anlatıcıları, onların yanına gelir ve sebebi anlaşılmayan bir kargaşa olur. O gözleri görmeyen kişiler döne döne bu iki sevdalıya ağlarlar. Film baştan sona Hazal'ın olmaması gereken evliliğinin bir trajedisidir. Üstelik dindar bir yaşam sürmeye çalıştığını zanneden köylü, böyle bir kıyıma göz yummakla birçok sıkıntıya maruz kalmıştır.

\subsection{Sultan Gelin}

"Sultan Gelin" filminin yönetmenliğini ve senaristliğini Halit Refiğg, yapımcılığını Hulki Saner yapmıştır. Dram türünde olan filmin senaryosu Cahit Atay'ın aynı isimdeki tiyatro eserinden uyarlanmıştır. Film, Hatay’ın Reyhanlı ilçesinin Harran Mahallesi'nde çekilmiştir. Halit Refĭğ'in olayların tamamının köyde geçtiği tek filmi 1973 yılında çekilen "Sultan Gelin”dir. Bu bağlamda film üzerinden Türk kültüründe kırsal kesimdeki kadının konumu ve sıkıntıları gözler önüne serilmiştir. Filmde, Doğu ve Güneydoğu Anadolu'da kadınların yaşamak zorunda kaldığı sıkıntılar, töre ve geleneklerin baskısı sahnelenir (Emin 2003: 46).

Filmde Türkan Şoray, Sultan ismiyle karşımıza çıkmaktadır. Film, başlık parasının pazarlığı ile başlar. Burada yapılan bu pazarlık, günümüz şartlarına göre bir mal, bir eşya satılması gibi değerlendirilebilir. Kıran kırana yapılan bir pazarlıktan sonra Sultan, ağanın kalp hastası oğlu Osman'a verilir. "Sultan Gelin" de "Hazal” filminden farksız bir şekilde filmin ana temasının habercisi bir mesajla başlar. Filmin başında bütün 
Fatma YILDIRMIŞ, “'Hazal' ve 'Sultan Gelin’ Filmleri Üzerinden Evliliğe İlişkin Geleneklerin Halk Bilimi Açısından Değerlendirilmesi”, Mavi Atlas, 7(2)/2019: 88-107

film boyunca iki kez daha tekrarlanan başlık parasının pazarlığı yapılır. Bu pazarlık boyunca kızın annesi ve babası bu durumdan gayet memnun, damadın babası maharetli, yetenekli, çabuk ve çevik bir gelin almaktan mutlu bir tablo çizmektedir.

Sultan ve Osman'ın düğünü en kısa zamanda yapılır. Yengesi geline yüzgörümlüğü gibi bazı talimatlarda bulunur. Damattan önce odaya damadın küçük kardeşi girer. Burada verilmek istenen mesaj, asıl güvey adayının onun olacağı bilgisidir. Damat yüzgörümlüğünü taktıktan sonra rahatsızlanır, bütün geceyi dinlenerek geçirir. Sultan bütün ahalinin kendinden beklediği işaret için bileğini keser ve haberini verir. Osman babasının sevinç için attığı silahın sesine dayanamaz ve hayatını kaybeder. Osman'ın babası, hem başlık parası zayi olmasın hem de bütün köy işlerini yapacak adam eksilmesin diye Osman'ın küçük kardeşi Veli’yle Sultan'ın evlenmesine karar verir. Sultan'ın ailesi bu işe "parmak kadar çocuk" diye şaşırsa da ağa, "Barnak kadar olduğuna ne bakan, bi de bakan ki gocaman delikanlı olmuş, hem bu işi memlekette ilk ben yapmiyom ya." diyerek aileyi ikna eder. Ağa, Veli'yi Sultan'ın kucağına vererek “Al sana acar bir oğlan, gönlünce büyüt, çıkart meydana.” der. Bundan sonra Sultan ile Veli, abla kardeş olup yaşar giderler. Ta ki Veli kocaman delikanlı olana kadar. Sultan'ın yengesi ona süslenip Veli'ye sevdiğini belli etmesi için nasihatlerde bulunur; fakat Veli, Sultan'1 ablası olarak görmektedir. Üstelik Veli, başka bir kıza gönlünü kaptırmıştır ve onunla evlenmek istemektedir. Veli, Sultan'ın sevgisini belli etmek için verdiği elmayı önemsememiş, sevdiği kızın verdiği elmayı iştahla yemiştir. Onları birlikte gören Sultan hiddetlenir ve bu duruma çok üzülür. Ağa da Sultan ile Veli'nin düğününü karısının doğumundan sonra yapmaya karar verir. Canla başla işlere sarılan Sultan, Veli'yle evleneceği günü beklerken, Veli bu evliliği istememektedir. Düğün gecesi Sultan da Veli'nin sevdiğinden ayrılmasına dayanamayarak onların sevgisine kıyamaz ve kaçmalarına yardımcı olur. Ağa Veli'yi öldürmeye niyetlenir ama Sultan her zamanki gibi kendini öne atar ve Veli’yi kurtarır. Ağanın Sultan'a söylediği sözler manidardır: 'E gelin sen ne olacaksın böyle, eşsiz, çocuksuz, dölsüz."

Sultan Gelin, en sonunda ağanın yeni doğan iki aylık oğluyla evlendirilir. Üçüncü kez başlık parasında anlaşıldıktan sonra ağa, bebeği alıp büyüyüp yetiştirmesi için Sultan'a verir. Sultan üçüncü güveye bakar kalır. Hâlbuki burada ağa; Sultan’1 değil, Sultan'ın bütün işleri çekip çevirmesinden dolayı kendi menfaatini düşünmektedir. Zira Sultan, yavaş yavaş yaşlanmaktadır. İki aylık bebek evlenecek çağa geldiğinde Sultan yaşlanmış olup anne olma çağını geçirecektir. Bu duruma ses çıkartılamayacağını bildiğinden kaderini sessizce kabullenir. Filmin son kısmında Sultan gelinin boş bir beşiği sallaması, Anadolu kadınının kaderine boyun eğmek zorunda olduğunu göstermektedir. 
Fatma YILDIRMIŞ, “'Hazal’ ve ‘Sultan Gelin’ Filmleri Üzerinden Evliliğe İlişkin Geleneklerin Halk Bilimi Açısından Değerlendirilmesi”, Mavi Atlas, 7(2)/2019: 88-107

\section{Halk Bilimi Açısından Bu İki Filmde Aktarılan Evliliğe İlişkin Gelenekler}

\subsection{Levirat Evlenme Çeşidi}

Toplumların tarihi, ekonomik ve toplumsal yapıları, yerleşim düzenleri, geçim kaynakları, gelenek ve görenekleri evlenme çeşitlerini de belirlemektedir. Ülkemizde ekonominin, dışa açılımın, kültürel değişmenin çok olduğu yerlerde evlenecek olan bireylerin birbirleriyle tanışıp evlenmeleri yaygınlaşırken geleneklere, örf ve âdetlere sıkı sıkıya tutunmuş yerlerde diğer evlenme çeşitlerinin daha yaygın olduğu görülmektedir.

İster çağdaş olsun ister geleneksel, dünyanın çeşitli bölgelerinde insanlar, istedikleri zaman istedikleri biçimde istedikleri insanla evlenme özgürlügüne sahip değildir. Evlilik kurumunun sadece iki kişi arasındaki duygusal birlikteliğin ötesinde sosyal, kültürel, ekonomik hatta siyasal işlevselliği, kurumun hem çeşitlenmesini hem de kendine ait kurallarla örülmesini sağlamıştır. Levirat evlilikler bu çeşitlemenin en iyi örneklerindendir (Cengiz 2009: 146).

Levirat (kayın biraderle evlilik) kocası ölen kadının kocasının erkek kardeşi ile evlendirilmesidir. Zira bir koca öldükten sonra ardından korunmaya muhtaç eşi ve çocukları kalmışsa, onlara bakacak ve aile bütünlügünü de bozmayacak bir evlilik yaptırılmasına yönelik olarak gerçekleştirilen bu evlilikler, aile büyüklerinin kararı ile gerçekleşmektedir (Bağlı ve Sever 2005: 10).

Levirat evliliği Amerika, Avustralya ve Afrika kıtalarında yaşayan bazı topluluklarda, Cahiliye Devri Arapları ve Hindular, Yahudiler ve Orta Asya göçebe kavimleri arasında yaygındır (Yüksel 2010: 2029-2030).

Türklerde görülen levirat evlilik çeşidine bakıldığında uygulamanın bahsi geçen toplumlarda uygulanandan daha farklı olduğunu söylenebilir. Eski Türk toplumlarında levirat erkeğin ölen ağabeyinin dul kalan eşiyle ya da dul kalan üvey annesiyle evlenmesi şeklinde gerçekleşir. Leviratın Türkler ile diğer toplumlar arasındaki en büyük farkı, erkek çocuğunun babası öldükten sonra üvey anneleri ile de evlenebilmeleridir (Yüksel 2010: 2031-2032). Türk toplumunda bu geleneğinin izleri ilk Türk devleti olan Hunlara, MÖ III. yüzyıla kadar takip edilebilmektedir (Yüksel 2010: 2032).

$\mathrm{Bu}$ geleneğin neredeyse bütün Türk toplulukları arasında yaygın bir şekilde görülmesinde, aile kurumu parçalanmamalı anlayışının da etkili olduğu bir gerçektir; fakat bu bölünmezlikteki sebep sadece mal paylaşımı ile ilgili değil aynı zamanda sahip çıkma, koruma içgüdüsü ile de bağlantılıdır. Zira kocası ölmüş kadınların ve çocuklarının kimsesiz kalmalarına ve fakirlik çekmelerine örflere göre müsaade edilmeyeceğinden bu 
şekilde bir evlilik bağı ile bu akrabalar korunarak gelecekleri güvence altına alınmış ve aile böylece bölünmemiş olur.

Kocası ölen kadın eğer istemezse levirat evliliğinin gerçekleşmeyeceğini savunan Ögel, levirat evliliğinin nedenini aile malının bölünmemesi amacıyla yapıldığı şeklindeki açıklamaları çok materyalist olarak görüp malın bölünmemesi düşüncesinin levirat geleneğinin sebeplerinden yalnızca bir tanesi olabileceğini savunmaktadır. Ögel, bunları bütüncül düşünmek gerektiğini söyleyerek bütün Türk topluluklarında kız evlendikten sonra kendi ailesiyle hukuki bağının kesildiğini, gelinin artık koca evinin bir parçası olduğunu ve koca evinin gelin üzerindeki hakkını ve hukukunu devam ettirdiğini ifade eder (Ögel 2001: 256-257).

Levirat türündeki evlenme biçimine Anadolu'da bilhassa Doğu ve Güneydoğu Anadolu Bölgesi'nde rastlanmaktadır. Levirat evliliğin nedenleri ise şu şekilde siralanabilir:

1. Levirat evliliğinin sosyokültürel nedenlerine baktığımızda, amca konumundaki kişinin, ölen ağabeyinin çocuklarını üvey baba eline bırakmaması gerekliliği anlayışı vardır. Ayrıca kayınbirader ile yengenin birbirlerini tanımaları da bu kararı almalarını kolaylaştıran sebeplerden birisidir.

2. Levirat evliliğini ortaya çıkaran nedenlerden biri de ölen ağabeyinin çocukları için yapılan fedakârlık olarak açıklanabilir. Fakat bu evlilikte kayınbiraderyenge ilişkisinden, karı-koca ilişkisine geçiş yaşanmakta; elbette ki bu durum her iki taraf için evliliğin başlangıcında karı-koca ilişkisi bakımından sorun yaşamalarına sebep olmaktadır. Evliliğin başlangıcında sıkıntı olan bu durum, çiftlerin söylediklerine göre zaman ilerledikçe aşılmaktadır.

3. Levirat türü evliliği her iki tarafın kendisi ve ailesi yönünden uygulanabilir kılan bir başka sebep ise, aile sırlarının dışarıdan başkalarının öğrenmesini önlemektir.

4. Levirat tipi evliliğin sosyokültürel nedenlerinden bir diğeri, bölgede hâkim olan törelere dayalı kurallardır. Toplumsal yaşamda insanların düşüncelerini, duygularını ve davranışlarını belirleyen, yönlendiren, kısıtlayan birtakım kuralların varlığı da bir gerçektir.

5. Çiftin yapmış olduğu beyanlarla töre adı verilen katı kurallar bağlamında değerlendirildiğinde, levirat evliliğinin sebeplerinden bir diğerinin de sosyal çevrenin dul kalan kadına yaptığı baskının etkili olduğunu göstermektedir.

6. Levirat türü evlilik sayesinde toprak ve malın bölünmemesi, işgücü kaybının yaşanmaması, aileyi bekâr oğulları için başlık parası vermekten kurtarması ve 
Fatma YILDIRMIŞ, “'Hazal’ ve ‘Sultan Gelin’ Filmleri Üzerinden Evliliğe İlişkin Geleneklerin Halk Bilimi Açısından Değerlendirilmesi”, Mavi Atlas, 7(2)/2019: 88-107

böylece geline verilmiş başlık da boşa gitmemesi sağlanır (Poyraz Tacoğlu 2011: 126130).

Çalışmaya konu olan "Hazal” filminde kocası ölen; bu nedenle de kocasının kardeşi Ömer'le evlenmek zorunda kalan Hazal'ın hikâyesi anlatılır. Filmde halk bilimsel olarak dikkat çeken taraf ise sırf başlık parası ödendi diye beş yaşında bir çocuk olan Ömer ile güzeller güzeli Hazal'ın levirat evliliğidir.

Levirat geleneğinin çağdaş Türk edebiyatında konu olarak işlendiği görülmektedir. Defalarca tiyatroda oynanmış ve sinemada film olarak çekilmiş Cahit Atay'a ait "Sultan Gelin" adlı hikâye, buna örnek gösterilebilir ki mezkûr konu, bu çalışmada işlenen iki filmden birisinin de temelini oluşturmaktadır. "Sultan Gelin" filminin kurulduğu ana tema, "kayınbiraderle evlendirme" olayıdır. Filmde ağanın hastalıklı oğluna başlık parası karşılığında eşya gibi verilen Sultan, düğün gecesi kocasının misafirlerin havaya sıktığı kurşunlardan korkarak kalp krizi geçirerek ölmesi üzerine gerdeğe girmeden dul kalır. Kayınpederi de Sultan için verdiği başlık parası boşa gitmesin diye Sultan gelini, beş yaşındaki tek oğlu Veli'yle evlendirir. Osman'ın babası hem başlık parası zayi olmasın hem de bütün köy işlerini yapacak adam eksilmesin diye Osman'ın küçük kardeşi Veli'yle Sultan'ın evlenmesine karar verir. Sultan'ın ailesi bu işe "parmak kadar çocuk" diye şaşırsa da ağa, "Barnak kadar olduğuna ne bakan, bi de bakan ki gocaman delikanlı olmuş, hem bu işi memlekette ilk ben yapmıyom ya." diyerek aileyi ikna eder. Ağa, Veli' yi Sultan'ın kucağına verir “Al sana acar bir oğlan, gönlünce büyüt, çıkart meydana.” der. Osman ve Veli'nin babasının sözlerinden bu geleneğin var olduğu, aktif bir şekilde de uygulandığı anlaşılmaktadır. Zira kızın babası bu evliliğe gönlü razı olmasa da sessiz kalmış, geleneğin bilgisi ve törenin yaptırım gücü onu bu durumu kabullenmeye zorlamıştır. Aynı şekilde Veli, Hayriye ile kaçtıktan sonra dügüun gecesi tekrar dul kalan Sultan, bu kez de Veli'nin küçük kardeşi olan iki aylık bebekle evlendirilmeye karar verilir. Tekrar başlık parası verilip üçüncü kez anlaşmaya varılır.

Kaderci bir anlayışla hareket eden kadın yaşadıklarına razı olur. Ailesi kızını kime uygun görürse onunla evlendirir. "Sultan Gelin" filminde Sultan, hayatını boş bir beşik sallayarak devam ettirmeye hazırlanmaktadır (Emin 2003: 49). Filmin acı bir sonla bitmesi, izleyenlere kırsal kesimdeki kadının çaresiz, ezilmiş olduğunu gösterir. Kadının söz sahibi olmadığı, geleceği hakkında karar veremediği, evleneceği kişiyi kendisi seçemediği ortadadır. Aslında bu durum, Türklerin eski örf ve âdetleriyle uyumlu bir şekilde ailelerin kararlarının gençlerinkinin önünde olduğunun göstergesidir. 
Fatma YILDIRMIŞ, “'Hazal’ ve ‘Sultan Gelin’ Filmleri Üzerinden Evliliğe İlişkin Geleneklerin Halk Bilimi Açısından Değerlendirilmesi”, Mavi Atlas, 7(2)/2019: 88-107

Kocası ölmüş kadınlar, geleneklerin ve ekonomik koşulların baskısıyla, kayınbiraderleriyle evlenmeye mecbur edilirler (Abisel 2005: 89). Kırsal kesim kadınlarının, kim olursa olsun beklentileri güzel bir yuva kurup, çoluk çocuğa karışıp evinin hanımı olmaktır. "Sultan Gelin” filminde, kayınbiraderi Veli' yi bekleyen Sultan'ın da Veli'ye evlenmek isteyen Hayriye'nin de hayalleri aynıdır. Sultan, Veli'yi Hayriye ile görünce hayal kırıklığını şu şekilde ifade eder: "10 yıl ne diye bekledim ben, ömrümü böyle mi tüketeceğim. Hayal ettiğim beşiğin bebelerini Hayriye kız mı rrgalayacak." Hayriye de Sultan ve Veli'nin düğün törenine geldiği zaman tek isteğinin Veli'ye kavuşmak olduğunu, eğer olmazsa ölümü bile göze aldığını şu şekilde dile getirir: "Sen evlenince ben yaşayamam."

\subsection{Kaçma/Kaçırma Yoluyla Evlilik}

"Hazal" filminde leviratla evlenmenin haricinde kaçma yoluyla da gerçekleşen evlilik görülmektedir. Hazal, kaderine karşı gelerek duvarcı ustası Emin ile kaçar; fakat birlikte olmalarına rağmen bir evlilik gerçekleşemeden ölümle cezalandırılırlar.

"Sultan Gelin" filminde de aynı şekilde kaçma-kaçırma yoluyla gerçekleşen evlilik çeşidi ile karşılaşılmaktadır. Sultan ile Veli'nin düğün gecesi Veli, âşı olduğu ağa kızı Hayriye ile kaçar. Öyle ki bu kaçma olayını fark eden Sultan, gönlü razı olmasa da gençlerin sevdasının önünde durmayarak sürecin gerçekleşmesi için onlara yardım eder. Aslında gençlerin sevdalarına, isteklerine sahip çıkması Sultan'ın da kendini ve düzeni sorgulamaya başlamasını sağlar. Bu nedenle de kayınpederine karşı onları savunarak ölümden kurtarır. Zira Hayriye'nin sevdiğiyle kaçması, kırsal kesimdeki gençlerin belli bir değişime ihtiyaç duyduğunu, kadınların kendileri hakkında verilecek kararları tek başına ailenin inisiyatifine bırakmak istemediklerini, bunun için mücadeleye hazır olduklarını, evleneceği insanı seçme özgürlüğünün kendilerine ait olduğunu anlatmaktadir.

\subsection{Evlilik İsteğinin Belirtilmesi}

Anadolu'da, kırsal kesimde genç kız ve erkeklerin evlenme istekleri farklı biçimlerde fakat geleneksel olarak ifade edilir. Bu istekler cinsiyete göre değişiklikler gösterir. Toplumda saygı gereği bir bireyin evlenme isteğini aile büyüklerine açık açık söylemesi, tasvip edilmeyen bir uygulamadır. Bu nedenledir ki gençler dolaylı, imalı yollara başvururlar (Tezcan 1983: 133). Kızın da erkeğin de bu dönemde davranışları değişir. Gençlere karşı ailenin davranışlarında da değişme olmaktadır. Kızların içine kapanıklığı, erkeklerin asiliği dikkati çekmekte olan davranışlardandır. Erkeklerin sık sık traş olmaları, ayna karşısından ayrılmamaları, huzursuzluk yaratmaları; kızların 
Fatma YILDIRMIŞ, “'Hazal' ve 'Sultan Gelin’ Filmleri Üzerinden Evliliğe İlişkin Geleneklerin Halk Bilimi Açısından Değerlendirilmesi”, Mavi Atlas, 7(2)/2019: 88-107

bulaşıkları sert hareketlerle yıkamaları gibi hareketler, evlenme isteklerinin sembolik hareketleri, sözsüz iletişimlerinin ifadesidir. Buluğ çağına eren kız, oyundan elini eteğini çekip, ev işlerine yoğunlaşmaktadır (Altun 2004: 236).

Buna paralel olarak "Hazal" filminde evlilik isteğinin belirtilmesi ise Hazal'ın görümcesi olan Feşo'da görülmektedir. Feşo evlenmek istemektedir, bir belirteç olarak beyaz başörtüsünün üzerine kırmızı örtü bağlamaktadır. Evlenme isteğini belirtmek üzere kırmızı başörtü takma âdeti farklı yörelerde de görülür. Üstelik Feşo bir gün annesiyle başlık parası yüzünden evlenemediğini, sadece oğlunu düşündüğünü, kendisinin gönlü olup olmadığını düşünmediğini söyleyerek tartışır ve evlenmek istediğini açık açık dile getirir. Zira annesinin sesine kulak vermediği Feşo, yasak bir ilişki yaşamış, sonrasında muradına erememiş olmanın nişanı olarak kırmızı başörtüsünü ağacın dalına bağlamış ve canına kıymıştır. Aynı zamanda duvarcı Emin, firsat buldukça Hazal'ın karşısına çıkar. Onun Hazal'ın karşısına sürekli çıkması, onu düşünüp beklediğini söylemesi onu sevdiğinin, evlenmek istediğinin işareti olarak sayılabilir.

"Sultan Gelin" filminde Sultan, kocasının ölümünden sonra büyüyünce kayınbiraderi Veli ile evlenecektir. Veli büyümüştür ve Sultan artık evlenmek istediğini belirtmek için ayna karşısında süslenir. Veli, Sultan'ın süslendiğini fark etmeyince yengesi Sultan'a sevdiğini belli etmesi için ona elma vermesini öğütler. Sultan, Veli'nin eve geldiği sırada ona ağaçtan koparıp manalı bakışlarla cennet hurması uzatır ama Veli kabul etmez. Sultan Veli' yi takip eder ve onun başka bir kızla buluştuğuna şahit olur. Kız Veli’ye kırmızı bir elma uzatır ki Veli o elmayı iştahla yer. Sultan bu duruma çok üzülür zira onun evlenmek istediği kişi başkasıyla evlenmek istemekte onun verdiği meyveyi yemektedir.

Evlenme isteğinin belirtilmesi geleneğine halkbilimsel olarak baktığımızda evlenecek kızın süslenmesi, sevdiğine meyve vermesi, kırmızı başörtü takması gibi uygulamalar dikkat çekmektedir. Bu gelenekler herkes tarafından bilinmekte, sessiz sedasız yapılmaktadır.

\subsection{Başlık Geleneği}

Başlık, erkeğin ailesinin kızın ailesine verdiği genellikle nakit para ve eşyadır. Başlığa "bedel”, "kalın”, “ağırlık” adı da verilmektedir (Örnek 2000: 201). Geçmişi 1500 yıl önceye kadar dayandırılan "başlık veya kalın âdeti” Türkistan'dan Anadolu'ya, tarih boyunca yaşamlarını sürdüren bütün Türk boy ve oymaklarında uygulanmıştır. Söz konusu sözcügün Türk Topluluklarında kullanılış biçimi için şu örnekleri verebiliriz: 
Fatma YILDIRMIŞ, “'Hazal’ ve ‘Sultan Gelin’ Filmleri Üzerinden Evliliğe İlişkin Geleneklerin Halk Bilimi Açısından Değerlendirilmesi”, Mavi Atlas, 7(2)/2019: 88-107

Göktürklerde kalin, kalıng: Başlık, mal, servet, kalın, çeyiz.

Oğuzlarda kalıng: Öncül mihir olarak kadına erilen çeyiz.

Dede Korkut Oğuzlarında kalınlık: Evlenen kızın kalınlığı, çeyizlik, başlık.

Kazaklarda kalın mal: Başlık parası, kız tarafına verilecek başlık.

Kürtlerde kalen, kelen: Kızın babasına başlık olarak verilen para, başlık.

Altay Türklerinde kalım: Damadın kızın babasına verdiği para veya hayvan.

Azerbaycan Kürtlerinde kalin: Nikâh esnasında kızın babasına ödenen bedel.

Osmanlılarda kalın - başlık: Başlık.

Zazalarda kalın: Başlık (Turan 1991: 39).

Tarım ve hayvancılıkla uğraşan topluluklarda "başlık" konusu evlenme sürecinde ortaya çıkar. Kırsal kesimde insanlar ve hayvanlar "baş” sözcüğüyle sayılır. Örnek olarak "biz beş baş horantayız" diyen köylü, aile üye sayısının beş kişi olduğunu anlatmak ister ve kimlik cüzdanının adını da "kafa 'baş’ kâğıdı” der (Balaman 1983: 30).

Başlık verme veya ödeme geleneği bir kültür kalıbıdır, diğer bir ifade ile kendi kültürümüzün şartladığı bir davranış biçimidir. Bu konuda yapılmış olan kayıtların hemen bütünü gözden geçirildiğinde genellikle başlık denen ödemeye bazı yerlerde aynı zamanda ağırlık veya kalın; bazı yerlerde süt hakkı veya ana yolluğu da denmektedir. Bir kız için istenen başlık miktarı, büyük ölçüde bir evlilikten diğerine, köyden köye ve bölgeden bölgeye değişmektedir. Başlığın ödenmediği bazı bölgelerde (genellikle şehirler ve bir kısım kasabalarda ve özellikle Batı ve Kuzey Batı Anadolu bölgesinde) bunun yerine kız tarafi erkek tarafindan çeyiz olarak ev eşyası ve ziynet eşyası ister (düğün sandığı, düğün aynası, bir iki elbise, bir yatak, bir miktar altın bilezik ve küpe gibi). Yine Türkiye köy toplumlarında bazı yerde başlığın yanı sıra, akrabalık vazifesi olarak kız amcasına, dayısına, kızın erkek kardeşlerine hediye (halit veya halat) (tabanca, tüfek, at, elbise ve son yıllarda saat gibi değerli hediyeler) veya "para" da verilir. Başlık temel olarak gelin kız için ailesine ödenirse de bazı yerlerde dullara da gelin kıza oranla daha düşük bir fiyat olarak bazı yerlerde ise genç kızlara verilenden yüksek ödenebilir (Erdentuğ 1977:120-125).

Kalın, aile kurumunun kuruluşunu ve geleceğini düzenleyen bir depozittir. Kalın, harcanamaz veya uzun zaman saklanırdı. Erkek ailesinin "ailenin müşterek malı" olarak görülürdü. Bunun için ailenin her kişisinin, kız evine verilen bu malda, hakkı ve payı vardı (Ögel 1982: 395). Bütün Türk boylarında bilinen ve uygulanan "Kalın” veya 
“Başl1k”ın günümüzde şekil değiştirerek devam ettiğini söyleyebiliriz. Önceleri oğlan veya ailesi tarafindan kızın ailesine yapılan bir nevi evlilik ödemesi olan ve aileler arasında ekonomik bir bağ kurarak evliliğin daha istikrarlı olmasını sağlamak amacıyla yapılan bu uygulama daha sonra yozlaşarak, kızın mal gibi satılması şeklinde yanlış bir görünüm kazanmıştır. Günümüzde artık başlık adı altında bir para istenmemekle birlikte, kız tarafının istediği bilezik ve altına ödenen para çoğu zaman bunu geçmektedir (Çelik 1999: 417).

Yüzyıllardır halkın geleneğinde varlığını sürdüren başlık geleneği halk bilimin de ilgilendiği konulardan biri olmuştur. Kırsal yaşamdaki gelenekleri içeren her iki filmde de başlık geleneğinin uygulandığı görülmektedir. "Hazal" filminde başlık, herhangi bir miktar belirtilmeksizin bir pazarlık olmadan kutsal bir işlemmiş gibi dualarla ritüel şeklinde takdim edilir. Filmde çatı olarak başlık geleneğinin katı bir şekilde uygulandığ 1 bu nedenle de levirat yapıldığı görülmektedir.

"Sultan Gelin" daha önce de belirtildiği üzere bir başlık parasının pazarlığı ile başlar. Burada yapılan bu pazarlık, günümüz şartlarına göre bir mal, bir eşya satılması gibi değerlendirilebilir. Samanlı köyünün ağası olan damadın babası ve bir aracı, gelinin ailesiyle gündüz vakti ayaküstü pazarlık yapmaya başlar ki güzeller güzeli Sultan için talip çoktur. Köylü bir kadın yanlarına yaklaşır üç binde başlayan pazarlığı dört bine çıkartır. Kadın ile ağa arasındaki pazarlık, yedi bine kadar çıkınca kızın annesi onları daha da kızıştırmak adına iş yapan Sultan'a yaklaşıp onun ne kadar becerikli ve hızlı olduğunu göstermek için yapıp yapmadığı işleri sorunca Sultan, her işi yaptığını söyler. Ağa, bunları duyunca peşin para yedi bin beş yüz vererek Sultan'ı babasından alır. İki aile yakın zamanda düğün yapmak için anlaşırlar. Kızın annesi ve babası bu durumdan memnun olmuş, alacakları tarla için hayvan satacak iken Sultan'ın başlığıyla iki tarla alabilecek duruma gelmişlerdir. Aralarındaki konuşmada babasının Sultan'ın iyi para ettiğini söylemesi kız çocuğunun mal gibi alıp satıldığının, bu dönemde yedi bin beş yüz liranın ne kadar değerli olduğunun göstergesidir.

\section{5. Çeyiz Geleneği}

Çeyiz; evlenecek kız için kızın baba evinden götürdüğü önceden hazırlanmış eşyadır. Geleneksel kültürde, kız çocukları doğduktan sonra çeyiz hazırlıklarına başlanır. Çeyizin çokluğu kızların övünç kaynağı olduğuna inanılır. İçinde çeyiz yatak çarşafi, yastık kılıfı, yorgan yüzü, mendil, örtü vb. eşyalar vardır. Hazırlanan bez eşyaların tümü işlemelidir. Bunların kenarlarına dikilmek üzere oyalar, danteller, yazmalar, el örgüsü çoraplar çeyizin tamamlayıcı öğeleridir. Bunlara ailenin maddi durumuna göre birkaç 
yatak ve yorgan, iç çamaşırları, giysiler ile kilim, halı, bakır kap-kacak kıza verilen çeyiz eşyaları da eklenir (Karakaş 2005: 52) .

Çeyiz; kızın yeteneğini, başarısını, ailesinin de statüsünü ortaya koyar. Düğün öncesi çeyizin sergilenmesi de tamamen bu amaca yöneliktir. Aile, kılarına verdikleri önemi bu şekilde gözler önüne sererken, kız da kendi başarısını sergilemiş olur. Bütün bu özellikleriyle çeyiz Türk toplumunda çok önemli bir yere sahiptir. "Çeyiz yazma”, "çeyiz götürme", "çeyiz yerleştirme" vs. gibi her biri ayrı bir öneme sahip uygulamalar düğünlerin önemli süreçlerindendir (Çelik 1999: 360). Bazı yerlerde, çeyiz, kız evinde bazı yerlerde ise oğlan evine götürüldükten ve yerleştirildikten sonra gösterilir. Çeyizin oğlan evine götürülmesi, kimi yerlerde düğünden birkaç gün önce olurken, kimi yerlerde gelinle birlikte olur (Karakaş 2005: 52). Genellikle çeyiz, oğlan evine davul zurna eşliğinde bayrakla beraber götürülür (Artun 1998: 96).

Anadolu'nun bazı bölgelerinde kıı olan aile, zamanı geldiğinde çeyiz masraflarının karşılanması için bir kavak ağacı diker. Eskiden çeyiz eşyaları bez, dokuma tarzı iken günümüzde özellikle kentlerde evin temel ihtiyaçlarını karşılığı olmuştur. Kız tarafından çeyiz olarak; mutfak eşyası, yatak odası takımı, çamaşır makinesi gibi ev eşyası alması umulurken, oğlan tarafının; salon ve yemek odası takımları, buzdolabı, firın gibi temel ihtiyaçları alması beklenmektedir (Karakaş 2005: 52).

Filmlerde geçen çeyiz hazırlama, taşıma, serme işlemlerine halk bilimsel olarak baktığımızda geleneğe uygun olarak dügün öncesi veya sırasında uygulandığ1 görülmektedir. Her iki filmde de çeyiz geleneğinin yaşatılıp işlenmesi çeyizin düğün öncesinde taşınıp yerleştirilmesiyle olur. Genellikle kadınların yaptığı bu işlem çeyizin elden ele kız evinden erkek evine taşınıp yerleştirilmesi şeklindedir. Kısa bir sahne de olsa bunun gösterilmesi geleneklerin aktarımında sinemanın nasıl bir görev üstlendiğini ortaya koymaktadır.

\subsection{Düğün Geleneği}

Halk tefekküründe er yani evin reisi, erkeği koruyan kollayandır. Eri olmak, sahip olan1, koruyan1, kurtaranı olmaktır. Erli olmak, kocaya varmak, evlenmektir. Ersiz kalmak, eri ölmek, sahipsiz kalmaktır. Evlenmek, ev edinmek başını sokacak yuva edinmek, o yuvayı koruyucu edinmektir. Er, eşinin bayraktarıdır (Kalafat 2006:160). Anadolu kültüründe kadının erkeğine sahip çıkması, onu namusu bilmesi ve her şeye rağmen sesini çıkartmadan onun hizmetini görmesi halen yaygın olarak görülmektedir ki bu iki filmde de bu konu etkili bir şekilde işlenmiştir. 
"Hazal" filminde at üstünde kırmızı gelinliği ile kız evinden alınan Hazal'ın düğünü mutsuz, eğlencesiz, davul zurna çalmadan, oynanmadan yapılır, yenir içilir ve herkes dağılır. Ata bindirilen gelin rüzgârlı, puslu bir havada hüzünlü bir şekilde kadınlar eşliğinde erkek evine götürülür. "Sultan Gelin” filminde ise Sultan ile Osman'1n düğünü davul zurna eşliğinde halayların çekildiği, herkesin yiyip içip eğlendiği bir düğündür. Herkesin yüzü güler, bu evlilikten herkes mutludur. Halk bilimsel olarak her iki filmde evlilik için düğün geleneğinin uygulandığı, bu uygulamalarda bazı farklılıklar olsa da davul zurna eşliğinde eğlenilip, yenilip içildiği görülmektedir.

\subsection{Nikâh Geleneği}

Nikâh asli manada kız ile damadın evlendiklerinin delili, ilanıdır. Resmi ve dini olmak üzere iki çeşidi vardır. Özellikle kırsal kesimde son zamanlara kadar resmi nikâha önem verilmezken şimdilerde her ikisi de yapılmaya dikkat ediliyor. Türkiye'de an'anevi topluluklarda, evlenmenin hem kanuni ve hem de dini merasimi yapılır (Erdentuğ 1977: 76). Cumhuriyetten önce yegâne nikâh şekli şer'î nikâhtır. Cumhuriyet devrinde ise bu nikâh hukuken geçersiz sayılmış, bunun yerini, 1926'da kabul edilen Medenî Kanun'un öngördüğü resmî nikâh almıştır. Önceleri pek rağbet görmemesine rağmen, sağladığ1 avantajlar anlaşıldıkça, özellikle artık kadınlar resmi nikâh olmadan evlenmek istememekte, ama bunun yanında dini nikâh da varlığını sürdürmektedir (Çelik 1999: 365).

"Hazal" filminde doğrudan bir nikâh sahnesi görülmese de izleyicide başlık parası verilmesi sırasında nikâhın gerçekleştiği fikri uyandırılır. Yine Hazal ile Emin arasında beraber kaçtıktan sonra geçen konuşmada resmi nikâh yapacakları, Hazal'ın imam nikâhının geçerli olmadığı belirtilir. "Sultan Gelin" filminde düğün merasimi gerçekleşirken Sultan ve yengesinin arasındaki konuşmadan imam nikâhının gıyaben yapıldığı ve de gelin ve damadın düğünden önce birbirini görmedikleri anlaşılmaktadır.

\subsection{Yüzgörümlüğü Geleneği}

Düğünden sonra gelin ve damadın kalacağı yere "gerdek evi”, "gerdek damı", "gerdek odası" gibi isimler verilmektedir. Sağdıcı ve yakın arkadaşları tarafından eğlenceyle ve yumruklanarak damat, gerdek odasına sokulur. Bazı kesimlerde gelin ile damat birbirlerine sözlerini geçirmek amacıyla birbirlerinin ayaklarına basmaya çalışırlar. Bazı bölgelerde gelinin sandığında veya arkasından gelin ardı denilen yiyecek gönderilir. Bunlar pişirilmiş tavuk, baklava, çerez türünden yiyeceklerdir. Genellikle gelinin yanında bir yenge vardır. Yenge damat gelene kadar geline eşlik eder, gelini damada teslim ettikten sonra dışarı çıkar. Bu esnada gelin hiç konuşmaz, damat gelini konuşturmak için çeşitli yöntemlere başvurur. Aslında gelini konuşturmanın tek yöntemi 
Fatma YILDIRMIŞ, “'Hazal' ve 'Sultan Gelin’ Filmleri Üzerinden Evliliğe İlişkin Geleneklerin Halk Bilimi Açısından Değerlendirilmesi”, Mavi Atlas, 7(2)/2019: 88-107

“yüz görümlüğü” adı verilen hediyenin geline verilmesidir. (Santur 2009). Gelin, konuşursa tılsım bozulur; ne yapıp edip "ağırlık" almadan -yüz görümlüğü- yüzünü açmayacak ve konuşmayacaktır. Damat ucuz kurtulmak ya da açıkgöz davranmak için kızı konuşturmayı dener. Sonunda da işi uzatmadan kızın ağırlığını verir ve yüzünü açar. Bu sırada oğlan yengesi elinde tepsiyle içeri girer; iki fincan kahveyi damada ve geline sunar; onlara mutluluklar diler ve dişarı çıkar (Balaman 1983: 146).

"Hazal" filminde herhangi bir yüzgörümlüğü âdeti görülmezken küçük damat olan Ömer odaya girer, Hazal'ın duvağını kaldırır, gelin damadın elini öper. Küçük damat Ömer gerdek öncesi kılınan iki rekât namazı kılar ve yatağa girer. "Sultan Gelin" filminde yenge statüsündeki kişi Sultan'a akıl verir, yol yordam gösterir. Yengenin Sultan'a ödenen başlığın miktarının diğerlerine göre daha fazla olduğu bu nedenle de yüzgörümlüğü noktasında kendisini ağırdan satması için Sultan’a verdiği öğütler dikkati çekmektedir. Sultan evlendiği kişiyi görmemiş, adını bile ilk kez orada öğrenmiştir. Yenge, Sultan'a damat konuşmadan ve altın takmadan gelinin konuşmaması gerekir şeklinde son talimatını verip çıkar. Damat ise arkadaşlarının kollarında sırtından yumruklanarak gerdek odasından içeriye atılır. Kalbi zayıf olan Osman yumrukların etkisinden kurtulup kendisine gelince geline beşi birlik takar ve gelinin duvağını açar. Filmin devamında yorgun düşüp bayılan Osman bütün gece uyur. Kendisinden nişan beklenen Sultan bileğini keser ve kan akıtır, nişanı gönderir. Bunun üzerine damat tarafı havaya silahlar atarak bu olayı kutlarlar. Zaten filmde de Osman bu silahların sesine uyanır ve babasının kendisinden haber beklediğini ama onun uyuyakaldığı için onu mahcup ettiğini düşünerek korkar. Zayıf kalbi dayanamayan Osman oracıkça ölür.

\subsection{Duvak Geleneği}

Duvak, genellikle yeni evli çiftlerin eksik olan eşyalarını tamamlamak, onlara ihtiyacı olan maddi yardımı yapabilmek için düzenlenen merasime katılan misafirler bizzat yerinde görerek fikir edinirler. Duvak aynı zamanda damat tarafinın gelini yakından görmeleri, onunla tanışmaları için yapılır. Gelinin kocasının evinde yeni hayatı için ona tanınır bir çevre hazırlamaları anlamını taşır. Duvak, düğünün en son safhası olup gelinin iffetini ifade eden bir törendir.

"Hazal” filminde duvak geleneğinin eğlencesiz bir şekilde geçtiği görülmektedir. Hazal, kayınvalidesi ve görümcesi ile kapı eşiğine oturur. Gelen kadın misafirler, kayınvalideye hayırlar dileyerek gelinin güzelliğini överler ve giderler. "Sultan Gelin" filminde böyle bir geleneğin izi görülmemektedir. Zaten ilk düğün gecesinde damat ölür, ikinci düğün gecesinde damat başka biriyle kaçar, dolayısıyla düğün sonrası uygulanan 
Fatma YILDIRMIŞ, “'Hazal’ ve ‘Sultan Gelin’ Filmleri Üzerinden Evliliğe İlişkin Geleneklerin Halk Bilimi Açısından Değerlendirilmesi”, Mavi Atlas, 7(2)/2019: 88-107

âdetlere sıra gelmemiştir. Duvak geleneğine halk bilimsel olarak bakıldığında ve konu geçmiş günümüz mukayesesiyle değerlendirildiğinde görülecektir ki bu gelenek yavaş yavaş terkedilmeye ve unutulmaya başlamıştır.

\section{Sonuç}

Türkan Şoray’ın başrolünü oynadığı iki filmde de Anadolu kadınının vefakâr, cefakâr, anaç, savunmasız ama bir o kadar güçlü halleri sergilenmiştir. Geleneksel kesimlerde gerçekleştirilen evlilik çeşitleri, sosyal ilişkileri düzenleme ve anlaşmazlıkları çözme işlevini üstlenmektedir. Böylece geleneksel toplumlar için bazı durumlarda töre, örf, âdet, gelenek ve göreneklerden oluşan sosyal normlar, bazı durumlarda yazılı hukuk kurallarından çok daha etkili olabilmektedir. Her iki filmde de bu geleneklerin katı bir şekilde uygulandığı görülmektedir. Bunun yanında her iki filmde başlık parasının ehemmiyeti ve gelinlikle giren gelinin kefenle çıkacağı inancı vurgulanmış olur.

"Hazal" ve "Sultan Gelin" filmlerinde levirat ve kaçma yoluyla evlilik çeşidinin yanında evlilik isteğinin belirtilmesi, başlık, düğün, nikâh uygulanan ortak geleneklerdir. Yüzgörümlüğü sadece "Sultan Gelin" filminde, duvak geleneği ise sadece "Hazal" filminde işlenmiştir.

Her iki filmin son kısımları trajiktir. "Hazal" filmi zaten başladığı dakikadan itibaren izleyenlere bu kanıyı vermekle beraber Hazal' in her şeye, herkese rağmen kaderine karşı çıkmaya çalışması, mutlu olmak istemesi ve bunun için sevdiğine kaçması, bu uğurda savaş vermesi izleyici de bunca zaman böyle gelmiş devranın değişeceği fikrini uyandırsa da yine can sıkıcı bir sonuç gerçekleşmiştir. Köy tasviri bile oldukça iç karartıcı bir atmosfer taşır, görünen taşra, pastoralden ziyade ürkütücüdür. Konunun işlenişi trajedinin unsurlarını barındırır. Umut yoktur, ele alınan gerçeklik yakıcıdır, insafsızlığ 1 saklanmaz. "Sultan Gelin" filminde ise mutluluğun, hayallerin, bilmediği bir ortama gireceğinin tatlı telaşını yaşayan Sultan için de sonuç çok iç açıcı değildir. Kaderinin kurbanı olan Sultan başında bir koca, kucağında bebekleri olsun istemiş fakat bir türlü emellerine ulaşamamıştır. Hatta Veli'nin mutluluğuna izin vermiş, kaderinin böyle olmasını kabullenmiştir.

Geleneklere bir başkaldırışı anlatan "Hazal" filminde tiyatro senaryosuna daha münasip olan zaman zaman ara sahnelerde görülen kilim dokuyan körler, tıpkı bir koro sesli bir vicdan gibi köylünün iç sesi gibi konuşurlar: "Kan ne renktir, kırmızı ne renktir?" Zira bir değişim olacağı bellidir. Hazal çok güzel bir kadındır fakat kayınvalidesi kendinde olmayan güzelliğinin hırçınlığıyla güzel bir gelinden olacak çocukla soyunun devamını dilemektedir. Aynı zamanda da sert ve keskin davranışlarla ailesini yönetmeye 
çalışır. Fakat değişim başlamış kocası duruma en azından sessiz kalmış, kızı daha fazla dayanamayıp canına kıymış, oğlu ise başlardaki sert tavrını bırakıp Hazal'da anne şefkatini aramıştır. Hazal, her ne kadar hazin bir son olsa da değişimin başlangıcıdır. “Sultan Gelin” filminde değişim Veli’nin sevdiği ve birlikte kaçtı̆̆ı kızla görülmektedir. Artık kaderine karşı koymak, sevdiğine sahip çıkmak, aile büyüklerinin verdiği kararın her zaman doğru olmadığını görmek bu filmin sonundaki değişime yönelik işaretlerdir.

Sinema görsel bir sanattır ve içeriği sağlam bir film izleyicisinden tam not alacaktır. Türk filmi seyircisi de kendi kültürünü yansıtan, kendini bulduğu filmleri daha çok benimsemiş, sevmiş, belleğinde taşımış ve bu filmleri zevkle izlemiştir. İşte burada her yönüyle konu olarak halka ait bütün değerlerin işlendiği bu iki film örneğinden anlaşılacağ1 üzere halk bilimin unsurları uygulamalı olarak sinema sahnesinde ele alınmıştır. Halk bilimi ürünlerinde olması gereken artık yaşatmak için yaymak düşüncesiyle uygulanmak olmalıdır. Hal böyleyken sinema, tiyatro gibi görsel sanatlar, uygulamalı bir şekilde halk kültürünü yaşatmak için yaymak ilkesine dayalı bir şekilde folklorik öğelerin geniş halk kitlesine ulaşması yönüyle önemli görevler üstlenmektedir. $\mathrm{Bu}$ bağlamda Türk halk bilimcilerin kültürel miras belleği ile iletişim alanında çalışanların disiplinler arası araştırmalar yapması sürecin devamında gerekli hale gelmiştir.

\section{Kaynakça}

ABİSEL Nilgün (2005). Türk Sinemast Üzerine Notlar, Ankara: Phoenix Yayınevi.

ALTUN, Işık (2004). Kandıra Türkmenlerinde Doğum, Evlenme ve Ölüm, İzmit: Yayınc1 Yayınları.

ARTUN, Erman (1998). "Tekirdağ Halk Klütüründe Geçiş Dönemleri DoğumEvlenme-Ölüm”, Bir, Türk Dünyası İncelemeleri Dergisi, (9-10): 85-107.

BAĞLI, Mazhar ve SEVER, Aysan (2005). “Tabulaştırılan/Tabulaşan Kurumun (Ailenin) Kurbanlıklar Edinme Pratiği: Levirat ve Sororat”, Aile ve Toplum, 2(8): 9-21.

BALAMAN, Ali Rıza (1983). Gelenekler Töre ve Törenler, 1. Basım, İzmir: Betim Yayınları. 
Fatma YILDIRMIŞ, “'Hazal' ve 'Sultan Gelin’ Filmleri Üzerinden Evliliğe İlişkin Geleneklerin Halk Bilimi Açısından Değerlendirilmesi”, Mavi Atlas, 7(2)/2019: 88-107

CANDEMIR, Tülin (2006). "Türk Sinema Afişlerinde Geleneksel Kültürel Göstergeleri” International Symposium of Traditional Art, Dokuz Eylül Üniversity Faculty ok Fine Arts Traditional Arts Department, 2: 581-590.

CENGIZZ Tülin B. (2009). "Levirat Evliliklere Hitit Hukukundan Bir Referans", Kocaeli Üniversitesi Fen Edebiyat Fakültesi Sosyal Bilimler Araştırma Dergisi, 2: 143151.

ÇELİK, Ali (1999). Trabzon Şarpazarı Çepni Kültürü, Trabzon: Ofset Mat.

EMIN, Bilge (2003). Halit Refĭg Sinemasında Kadın (1960/61 - 2000), (Yayımlanmamış Yüksek Lisans Tezi), Ankara Üniversitesi Sosyal Bilimler Enstitüsü Radyo-Televizyon ve Sinema Anabilim Dalı. Ankara.

ERDENTUĞ, Nermin (1977). Sosyal Âdet ve Gelenekler, Ankara: Kültür Bakanlığı Yayınları.

KALAFAT, Yaşar (2006). Doğu Anadolu'da Eski Türk İnançlarının İzleri, 5. Basım, Ankara: Babil Yayıncılık.

KARAKAŞ, Ayhan (2005). Feke Halk Kültürü Araştırması, (Yayımlanmamış Yüksek Lisans Tezi), Çukurova Üniversitesi Sosyal Bilimler Enstitüsü, Adana.

OĞUZ, Öcal (2002). Küreselleşme ve Uygulamalı Halkbilimi, Ankara: Akçağ Yayınc1lık.

ÖGEL, Bahaeddin (2001). Dünden Bugüne Türk Kültürünün Gelişme Çă̆larl, İstanbul: Türk Dünyası Araştırmaları Vakfı Yayınları.

ÖGEL, Bahaeddin (1982). "Türklerde Kalın ve Başlık”, II. Milletlerarası Türk Folklor Kongresi Bildirileri, IV. Cilt, ss. 393-396, Ankara: G.Ü. Basın-Yayın Yüksekokulu Basımevi.

ÖRNEK, Sedat Veyis (2000). Türk Halk Bilimi, Ankara: Kültür Bakanlığ Yayınlar1.

POYRAZ TACOĞLU, Tuğça (2011). "Türkiye'de Gerçekleştirilen Geleneksel Evlilik Çeşitlerinin Nedenleri ve Evlilikler Üzerine Törenin Etkisi”, ODÜ Sosyal Bilimler Enstitüsü Sosyal Bilimler Araştırma Dergisi, 2 (4): 114-143.

SANTUR, Meltem Emine (2009). "Evlenme Adetleri”, Erişim Tarihi: 18.10.2009, (http: / / tukoloji.cu.edu.tr /halkbilım/27. php.). 
Fatma YILDIRMIŞ, “'Hazal' ve 'Sultan Gelin' Filmleri Üzerinden Evliliğe İlişkin Geleneklerin Halk Bilimi Açısından Değerlendirilmesi”, Mavi Atlas, 7(2)/2019: 88-107

SÖZEN, Mustafa (2009). "Doğu Anlatı Gelenekleri ve Türk Sinemasının Aidiyeti”, Bilig, 50: 131-152.

TEPEKÖYLÜ, İlke (2016). "Halk Edebiyatı Anlatı Türlerinin Uygulamalı Halk Bilimi Bağlamında Türk Sinemasındaki İzdüşümleri”, Turkish Studies, 11(4): 1001-1014.

TEZCAN, Mahmut (1983). "Köy Gençlerinin Evlenme İsteklerine İlişkin Davranış Kalıpları”, Ankara Üniversitesi Eğitim Fakültesi Dergisi, 16 (2): 133-136.

TURAN, Ahmet (1991). "Törelerimizde Kalın (Başlık) Âdeti”, Milli Folklor, (12): 39-43.

YÜKSEL, Musa Şamil (2010). "Türk Kültüründe "Levirat” ve Timurlularda Uygulanışı”, Turkish Studies 5(3): 2027-2058. 
Fatma YILDIRMIŞ, “'Hazal' ve 'Sultan Gelin’ Filmleri Üzerinden Evliliğe İlişkin Geleneklerin Halk Bilimi Açısından Değerlendirilmesi”, Mavi Atlas, 7(2)/2019: 88-107

\section{Ekler}

Şekil 1: "Sultan Gelin” Film Afiş̧i

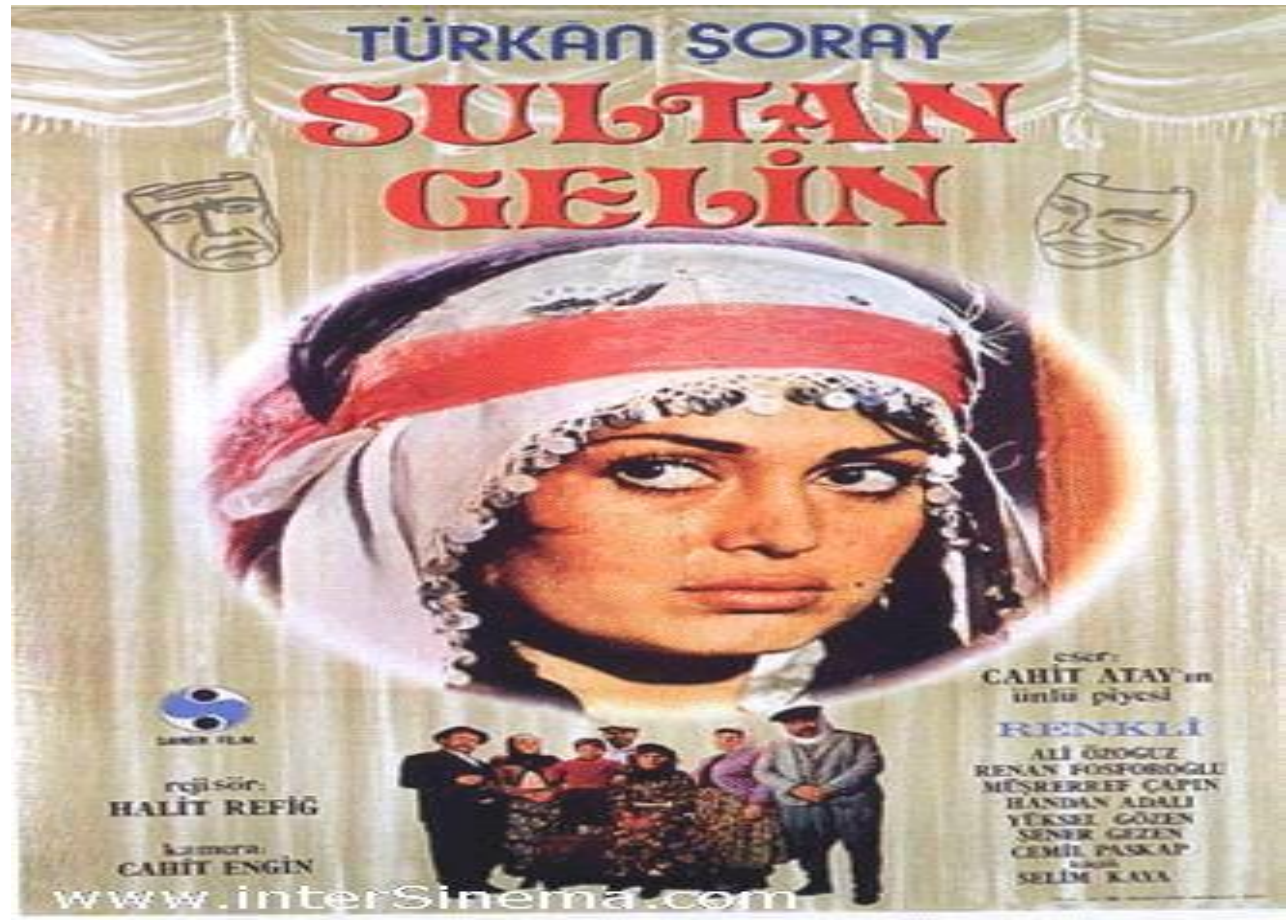

Şekil 2: "Hazal" Film Afişi

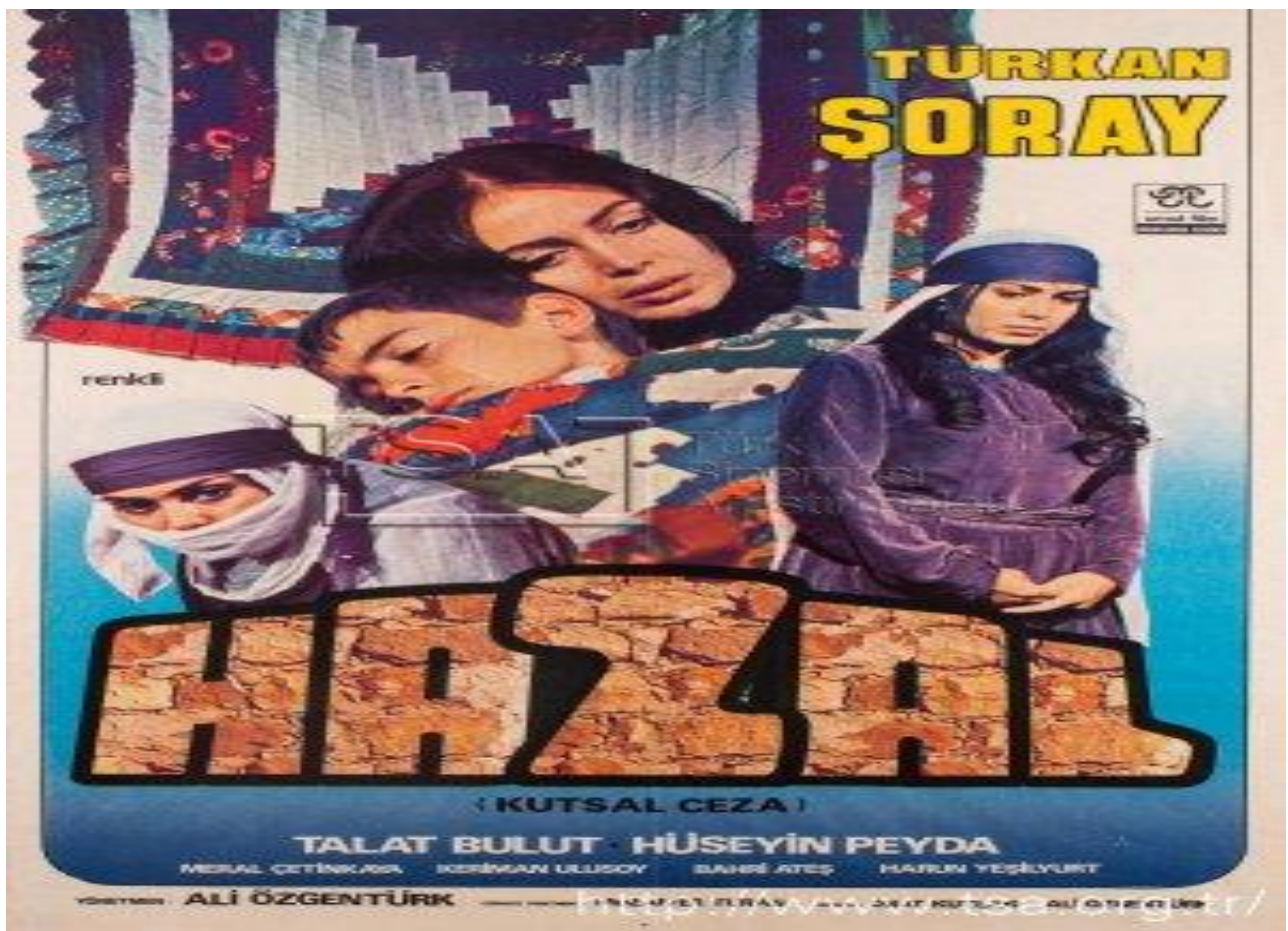

